\title{
Production of Antiseptic Tablet Aloe Vera Soap
}

\author{
Muhammad Sulaiman Rahama \\ Department of pure and Industrial Chemistry \\ Umaru Musa Yar'adua University \\ Katsina, Nigeria
}

\author{
Abubakar Sani \\ Department of pure and Industrial Chemistry \\ Umaru Musa Yar'adua University \\ Katsina, Nigeria
}

\begin{abstract}
This research work aimed at investigating some phytochemical constituents present in aloe vera based antiseptic soap and its activity against some selected microorganisms. The soap was produced using hot process and the antimicrobial activity was performed against Staphylococcus aureus, Escherichia Coli and Candida albicans using the method of agar well diffusion. The produced soap exhibited highest zone of inhibition on Staphylococcus aureus with 8.6 $\mathrm{mm}, 10.1 \mathrm{~mm}, 13.8 \mathrm{~mm}$ and $15.1 \mathrm{~mm}$ at $25 \mathrm{mg} / \mathrm{mL}, 50$ $\mathrm{mg} / \mathrm{mL}, 100 \mathrm{mg} / \mathrm{mL}$ and $200 \mathrm{mg} / \mathrm{mL}$ respectively, no inhibition was observed on E. Coli while the C. albicans was slightly inhibited by the soap by $7.6 \mathrm{~mm}, 9.0 \mathrm{~mm}$, $13.2 \mathrm{~mm}$ at $50 \mathrm{mg} / \mathrm{mL}, 100 \mathrm{mg} / \mathrm{mL}, 200 \mathrm{mg} / \mathrm{mL}$ respectively. The phytochemical screening conducted confirmed the presence of tannins, saponins, reducing sugar and flavonoid in the plant extract. The results of the investigations clearly indicated that aloe vera based soap had possessed antimicrobial activity against the tested microorganisms due to the presence of the confirmned phytoconstituents. Likewise pH, formability, and antimicrobial activity of the produced soap were comparable with the commercial soap.
\end{abstract}

Keywords:- Phytochemical Screening, Antiseptic Soap, Microorganisms, Agar Well Diffusion, Antimicrobial Activity.

\section{INTRODUCTION}

Soap is defined as a mixture of chemical compounds resulting from the interaction of fatty acids with a metal radical. Soap may also be described as any water-soluble salt of those fatty acids which contain eight or more carbon atoms. The metals commonly used in soap making are sodium and potassium, which produce water-soluble soaps that are used for laundry and cleaning purposes [1].

Soap is produced by the saponification of a triglyceride, the triglyceride is reacted with a strong alkali such as; $\mathrm{KOH}$ or $\mathrm{NaOH}$ to produce glycerol and fatty acid salts [2].

Antiseptic soap is an alteration of an ordinary soap where bioactive ingredients are added into the basic soap medium to produce a variety of biological effects to the product [3]. But due to the likelihood of causing side effects as a result of use of synthetic substances, it is important to avoid the use harmful synthetic chemicals from antiseptic soap products [4]. The plant based natural products have become another source that is used to enhance the important biological characteristics of medicinal soaps [5]. Coconut oil, vera extract, olive oil, venivel, neem oil, sandalwood, turmeric and jasmine are few of the most commonly found substances in skin care products including Antiseptic soaps [6].

Aloe vera is a plant that has narrow green leaves filled with viscous gel and possesses distinct margin with needles [7], it readily grows in hot and dry climates [8], and the gel is used in making different products and preparation of cosmetics [9]. Furthermore, it contains over hundreds of nutrients and bio-active compounds, like enzymes, vitamins, sugars, minerals, lignin, saponins, anthraquinones, salicylic acid and amino acids[10], in addition, its secondary metabolites possess many properties which include antiinflammatory [11], antibacterial [12], antioxidant [13], immune boosting, anticancer, [7] antidiabetic, anti-ageing and sunburn relief [14].

\section{METHODOLOGY}

\section{A. Sample Collection}

Aloe vera leaves were obtained from home garden in Katsina state. The leaves were stored in refrigerator to protect it from sunlight.

\section{B. Extraction of Aloe Vera Gel}

$982 \mathrm{~g}$ of fresh leaves of Aloe vera was accurately weighed using electronic weighing balance; washed with water to remove the dirt and yellow substances called aloe latex that come out from the leaves. The leaves were arranged vertically in a bowl containing water to allow the yellow substance to continue coming out. The top of the leaves and spine at the edges of each leave of leaves were removed carefully to slice away the clear gel at the centre. The remaining gel was scooped using spoon and poured into a blender for grinding. Then the gel was poured into a container and stored in a refrigerator for further use.

\section{Saponification Value}

The saponification value is the number of milligrams of $\mathrm{KOH}$ or $\mathrm{NaOH}$ required to neutralize the fatty acid resulting from the complete hydrolysis of $1 \mathrm{~g}$ of fat. Therefore, the oil or fat to be used is olive oil, and the saponification value of olive oil is 0.135 .

Therefore, to find the quantity of $\mathrm{NaOH}$ (lye) that will be used to completely neutralize $188 \mathrm{~g}$ of olive oil, we use the formula;

Quantity of $\mathrm{NaOH}$ to be used = Pure weight of oil $\mathrm{x}$ the saponification value of the oil. 
Therefore, Quantity of lye to be use $=188 \mathrm{~g} \times 0.135 \mathrm{~g}=$ $25.38 \mathrm{~g}$ of $\mathrm{NaOH}$

\section{Production of Aloe Vera Soap}

$63 \mathrm{~cm}^{3}$ of $\mathrm{H}_{2} \mathrm{O}$ was boiled at $100^{\circ} \mathrm{C}$ and poured into a container, and then $25.38 \mathrm{~g}$ of sodium hydroxide $(\mathrm{NaOH})$ was also added to the container and stirred till it completely dissolved, then the solution was kept for an hour to cool down.

$188 \mathrm{~g}$ of olive oil melted in a burner was added into the solution and stirred until the solution became thick.

Lastly, the aloe vera gel was also added to the mixture and stirred; the mixture was allowed to stand for some time and then poured into a soap mould.

\section{E. Phytochemical Screening}

$>$ Test for Tannins: $0.5 \mathrm{~g}$ of aloe vera extract was boiled in $20 \mathrm{~cm}^{3}$ of distilled water in test tube and then filtered. Few drops of $0.1 \%$ ferric chloride was added to the filtrate. Brownish green or blue-black coloration indicated the presence of tannin [15].

$>$ Test for Flavonoids: $5 \mathrm{~cm}^{3}$ of dilute ammonia solution was added to a portion of aqeous filtrate of plant extract followed by addition of sulphuric acid $\left(\mathrm{H}_{2} \mathrm{SO}_{4}\right)$. The presence of a yellow solution which disappears on standing indicated the presence of flavonoids [16].

$>$ Test for Saponins: $2.0 \mathrm{~g}$ of the plant extract was boiled in $20 \mathrm{~cm}^{3}$ of distilled water in a water bath and filtered. 10 $\mathrm{cm}^{3}$ of the filtrate was mixed with $5 \mathrm{~cm}^{3}$ of distilled water and shaken vigorously for stable persistent forth [17].

$>$ Test for Reducing Sugar: $1 \mathrm{~cm}^{3}$ of Fehling's solution A and $B$ was added to $1 \mathrm{~cm}^{3}$ of aqueous filtrate of each sample was boiled in water; red precipitate indicated the presence of non-reducing sugar. [18].

\section{F. Antimicrobial Susceptibility Test}

$>$ Organisms Collection: The organisms were cultured and collected from Microbiology Department, Umaru Musa Yar'adua University.

$>$ Sample Preparation and Serial Dilution: 1g of each soap sample was weighed and dissolved in a sterile container containing $5 \mathrm{~cm}^{3}$ of distilled water to obtain a concentration of $200 \mathrm{mg} / \mathrm{mL}$, then $1 \mathrm{~cm}^{3}$ of it was transferred into the next container containing $4 \mathrm{~cm}^{3}$ of water to obtain a $100 \mathrm{mg} / \mathrm{mL}$ concentration, $50 \mathrm{mg} / \mathrm{mL}$ and $25 \mathrm{mg} / \mathrm{mL}$ concentrations were serially prepared via the same procedure and kept for further uses.

$>$ Media Preparation: 2.35g of Sabaroud Dextrose Agar (SDA) and 2.8g of Nutrient Agar (NA) were dissolved in $50 \mathrm{~cm}^{3}$ and $100 \mathrm{~cm}^{3}$ of distilled water respectively, shaken and heated, then autoclaved at $121^{\circ} \mathrm{C}$ for 15 minutes. The already prepared SDA (fungi) and NA (bacteria) were plated out and allowed to solidify.

$>$ Bacterial and Fungal Inoculation: $0.5 \mathrm{~cm}^{3}$ of bacterial suspension and fungal suspension were introduced into the plates of NA and SDA, followed by spreading using L-shape rod, it was then allowed to be absorbed.
$>$ Disc Preparation: Sterile disc pinched from filter paper were dispersed aseptically and allowed to be absorbed for 30 minutes, followed by introducing it into each of the labeled plates and incubated at $37^{\circ} \mathrm{C}$ for $24 \mathrm{hrs}$.

$>$ Inoculum Standardization: A loopful of each of candida albicans, staphylococcus aureus and Escherichia coli were transferred into a test tube containing sterile distilled water to obtain a heavy growth and compared with McFarland turbidity standard.

\section{G. Determination of Minimum Inhibitory Concentration (MIC) of Aloe Vera Soap}

The minimum inhibitory concentration (MIC) was determined as the least concentration that showed an inhibitory effect on test organism using tube method as described by Cheruiyot et al., (2009) [19]. The MIC was evaluated on the soap that showed antibacterial activity in the agar well diffusion assay. To achieve that, a serial dilution was made using nutrient broth up to the forth dilution. Then $5 \mathrm{~cm}^{3}$ of a solution (produced soap) (the concentration of $200 \mathrm{mg} / \mathrm{mL}, 100 \mathrm{mg} / \mathrm{mL}, 50 \mathrm{mg} / \mathrm{mL}$ and 25 $\mathrm{mg} / \mathrm{mL}$ ) was added aseptically to $5 \mathrm{~cm}^{3}$ of double strength medium and mixed by shaking. Using a fresh syringe, $5 \mathrm{~cm}^{3}$ of the mixture was transferred to the second test tube which contained $5 \mathrm{~cm}^{3}$ of the single strength medium. This too was mixed aseptically by shaking. The twelve test tubes containing the commercial soap solution served as control. Finally, to each test tube $0.2 \mathrm{~cm}^{3}$ inoculums of test organisms was added aseptically. The test tubes were covered with cotton wool and incubated at $37^{\circ} \mathrm{C}$ for 24 hours and then observed for turbidity and recorded. The lowest concentration of the solution that inhibited growth of the test organisms was noted as the MIC [20].

\section{H. Evaluation of Minimum Bactericidal Concentration $(M B C)$ of the Aloe Vera Soap}

The MBC of the soap were determined using the method described by (Adegboye et al., 2008)[21]. Samples were taken from tubes with no visible growth in the MIC assay and sub-cultured onto freshly prepared nutrient agar medium and later incubated at $37^{\circ} \mathrm{C}$ for 48 hours. The MBCs were taken as the lowest concentration of the soap that did not allow any bacterial growth on the surface of the agar plates.

\section{Qualitative Analysis}

$>\mathrm{pH}$ Analysis: The $\mathrm{pH}$ value of the soaps produced was analyzed using a $\mathrm{pH}$ meter (JENWAY) $2.0 \mathrm{~g}$ of the produce soaps was dissolved in $50 \mathrm{~cm}^{3}$ of deionized water and the $\mathrm{pH}$ determined using $\mathrm{pH}$ meter. This was done for produced soap and the commercial ones, the values were recorded. $3.0 \mathrm{~g}$ of the soap was dissolved into $150 \mathrm{~cm}^{3}$ of distilled hot water and allowed to dissolved, then about 3-4 drops of phenolphthalein indicator was added and purple color was produce, then the soap solution was titrated against $0.05 \mathrm{M} \mathrm{H}_{2} \mathrm{SO}_{4}$ until yellow color was observed which signifies the end point.

$>$ Formability Test: $1 \mathrm{~g}$ of soap was weighted and dissolved into $100 \mathrm{~cm}^{3}$ of distilled water in a $500 \mathrm{~cm}^{3}$ of measuring cylinder. The mixture was shaken vigorously for 2 minutes and allowed to stand for another 2 minutes. The 
ISSN No:-2456-2165

height of the foam was then measured and recorded. The soap procedure was done for the commercial soap in comparison.

\section{RESULTS AND DISCUSSION}

\begin{tabular}{|c|c|}
\hline Compounds & Result \\
\hline Tannins & + \\
\hline Flavonoids & + \\
\hline Saponins & + \\
\hline Reducing sugar & + \\
\hline
\end{tabular}

Table 1:- Results of Phytochemical Screening

Key:

$+=$ present.

Table 1 showed the phytochemical screening result of the aloe vera extract which indicated the presence of all phytochemicals tested. The results presented above are in total agreement withwhat was reported by (Raphael, 2012)[22] and (Bouchra, 2019)[23].

\begin{tabular}{|c|c|c|c|c|c|c|c|c||}
\hline \multirow{3}{*}{ Isolates } & \multicolumn{5}{|c||}{ Zone of inhibition against fractions (mm) } \\
\cline { 2 - 9 } & \multicolumn{3}{|c|}{$\begin{array}{c}\text { Produced soap } \\
\text { (mg/mL) }\end{array}$} & \multicolumn{3}{c||}{$\begin{array}{c}\text { Commercial Soap } \\
\text { (mg/mL) }\end{array}$} \\
\cline { 2 - 8 } & 200 & 100 & 50 & 25 & 200 & 100 & 50 & 25 \\
\hline $\boldsymbol{C} . \boldsymbol{A}$ & 13.2 & 9.0 & 7.6 & ND & 15.2 & 14.5 & 14.1 & 10.0 \\
\hline S. $\boldsymbol{A}$. & 15.1 & 13.8 & 10.1 & 8.6 & 17.4 & 16.9 & 14.2 & 12.6 \\
\hline E. $\boldsymbol{C}$. & ND & ND & ND & ND & 10.1 & 9.0 & ND & ND \\
\hline
\end{tabular}

Key:

CA: Candida albicans (fungi)

SA: Staphylococcus aureus (+v) bacteria.

EC: Escherichia Coli (-ve) bacteria.

ND: Not detected (no zone of inhibition)

The antimicrobial screening results reported in table II shows a strong inhibition mainly in the highest conc. (200 $\mathrm{mg} / \mathrm{mL}$ ) in both the produced soap and commercial one followed by a gradual decrease in inhibitory character up to the lowest concentration $(25 \mathrm{mg} / \mathrm{mL})$.

The results revealed that the concentration of antimicrobial activity of commercial aloe vera soap is more than that of the produced aloe vera soap, this is because the commercial one contained additional ingredients which increased its activity such as palm kernel oil, shea butter, cocoa poel ash, lime juice, native honey (Ren Black soap with aloe vera) as compared to the one produced which contained only the olive oil, $\mathrm{NaOH}$ and water. This concludes the fact that both soaps possessed antimicrobial activity by their virtue of inhibiting bacterial growth, similar findings were reported in (Barandozi, 2003) [24] and (Hamman, 2008) [25] literatures.

\begin{tabular}{|c|c|c|c|c|c|c|c|c|}
\hline \multirow{3}{*}{ Isolates } & \multicolumn{4}{|c|}{ Zone of inhibition against fractions (mm) } \\
\cline { 2 - 10 } & \multicolumn{3}{|c|}{$\begin{array}{c}\text { Produced soap } \\
\text { (mg/mL) }\end{array}$} & \multicolumn{4}{c|}{$\begin{array}{c}\text { Commercial Soap } \\
\text { (mg/mL) }\end{array}$} \\
\cline { 2 - 10 } & 200 & 100 & 50 & 25 & 200 & 100 & 50 & 25 \\
\hline C. $\boldsymbol{A}$ & + & + & + & - & + & + & + & - \\
\hline S. $\boldsymbol{A}$. & + & + & - & - & + & + & + & - \\
\hline E. $\boldsymbol{C}$. & + & + & + & + & + & + & + & + \\
\hline
\end{tabular}

Table 3:- Results of Minimum Inhibitory Concentration (MIC)

Key:

C. $A=$ Candida Albicans

S. A= Staphylococcus Aureus

E. $C=$ Escherichia Coli

$+=$ absence of turbidity

- = presence of turbidity

\begin{tabular}{|c|c|c|c|c|c|c|c|c|}
\hline \multirow{2}{*}{ Isolates } & \multicolumn{3}{|c|}{ Zone of inhibition against fractions (mm) } \\
\cline { 2 - 9 } & \multicolumn{3}{|c|}{$\begin{array}{c}\text { Produced soap } \\
(\mathbf{m g} / \mathbf{m L})\end{array}$} & \multicolumn{5}{c|}{$\begin{array}{c}\text { Commercial Soap } \\
(\mathbf{m g} / \mathbf{m L})\end{array}$} \\
\cline { 2 - 9 } & 200 & 100 & 50 & 25 & 200 & 100 & 50 & 25 \\
\hline C. $\boldsymbol{A}$ & - & - & - & - & + & - & - & - \\
\hline S. $\boldsymbol{A}$. & + & + & - & - & + & + & - & - \\
\hline E. $\boldsymbol{C}$. & + & + & - & - & + & + & + & + \\
\hline
\end{tabular}

Key:

C. $A=$ Candida Albicans

S. A= Staphylococcus Aureus

E. $C=$ Escherichia Coli

$+=$ absence of turbidity

- = presence of turbidity

The MIC of the soap samples reported in table III had wide effect against $E$. Coli in all the concentrations which shows the absence of turbidity in both the produced and commercial soaps. Then the MBCs of the soap samples highlighted in table IV showed the absence of turbidity at $200 \mathrm{mg} / \mathrm{mL}$ and $100 \mathrm{mg} / \mathrm{mL}$ concentration against $S$. aureus and $E$. coli and failed to inhibit the growth of $C$. albicans in all the concentration of the produced soap.

\begin{tabular}{|c|c|c|}
\hline Soap & $\begin{array}{c}\mathrm{pH} \\
\text { Value }\end{array}$ & $\begin{array}{c}\text { Formability } \\
\text { result }\end{array}$ \\
\hline Produced soap & 10.1 & $160 \mathrm{~cm}$ \\
\hline Commercial soap & 9.8 & $190 \mathrm{~cm}$ \\
\hline Table 5:- Results of pH and Formability of the Soap \\
Samples
\end{tabular}

The $\mathrm{pH}$ values obtained in table $\mathrm{V}$ above revealed that all the values fell within the $\mathrm{pH}$ acceptable range (9-11), this finding is in agreement with what was reported by Vivian $e t$ $a l ., 2014$ [26]. The $\mathrm{pH}$ values obtained indicated that the soap would be less corrosive and would produce less skin reaction when used as reported by (Atolani et al., 2016)[27]. Likewise the forming ability of commercial soap was higher than the one produced by the produced soap. 


\section{CONCLUSION}

This research showed that the soap was successfully produced using aloe vera extract, it possessed antimicrobial activity from the results obtained, and thus could be used as antiseptic soap.

\section{ACKNOWLEDGMENT}

The authors gratefully acknowledge Engr. Dr. Ahmed Lawal Mashi for reviewing this manuscript kindly.

\section{REFERENCES}

[1]. A. Kuntom, W.L. Siew, and Y.A. Tan, "Characterization of palm acid oil" J. Am. Oil Chem Soc, vol. 71, pp. 525-528, 1994

[2]. U.P. Albert , Y. Yuri, "Soap bar performance evaluation method" J. of Am. Chem. Soc., vol. 13 (3), pp. 345-347, 2015

[3]. P. Kareru, J.M. Keriko, G.M. Kenji, G. Thiong 'o, A.N. Gachanja and H.N. Mukiira, "Antimicrobial activities of skincare preparations from plant extracts" Afr J Trad CAM, vol. 7(3), pp 214-218, 2010

[4]. A.S. Ribeiro, M. Estanqueiro, M.B. Oliveira and L.J.M. Sousa, "Main benefits and applicability of plant extracts in skin care products" Cosmetics, vol. 2, pp. $48-65,2015$

[5]. S. Ungphaiboon, T. Supavita, P. Singchangchai, S. Sungkarak, P. Rattanasuwan and A. Itharat, "Study on antioxidant and antimicrobial activities of turmeric clear liquid soap for wound treatment of HIV patients". Song. J. Sci. Tech., vol. 27(2), pp. 569-578, 2005

[6]. P. Shivanand, M. Nilam and D. Viral, "Herbs play an important role in the field of cosmetics", Int J. Pharm.Tech. Res., vol. 2(1), pp. 632-639, 2010

[7]. L. Zaira, K. Peter, A.N. Guadalupe, B.G. Virgilio, A.R. José, R.C. Rosalía, and R. Gildardo, "Cytotoxic Effects of Sábila (Aloe Vera): Commercial Products as Food Supplement", J. of Chem. Bio. and Phy. Sci., vol 4(5), pp. 47-54, 2014.

[8]. B.K Vogler and E. Ernst, "Aloe vera: a systematic review of its clinical effectiveness", Br. J. Gen. Pract., vol. 49, pp. 823-828, 1999.

[9]. M.Y. Wani, N. Hasan and M.A. Malik, "Chitosan and Aloe vera: two gifts of nature" J. Dispers. Sci. Technol., vol. 31, pp. 799-811, 2010

[10]. Y.I. Park and T.H. Jo, "Perspective of industrial application of Aloe vera". In: Park, Y.I., Lee, S.K. (Eds.), New Perspective on Aloe. Springer Verlag, New York, USA, pp. 191-200, 2006

[11]. S. Bhattacharjee, S. Paul, S. Dutta and T.K. Chaudhuri, "Anti-inflammatory and protective properties of Aloe vera leaf crude gel in carrageenan induced acute inflammatory rat models", Int. J. Pharm. Pharm. Sci., vol. 6, pp. 368-371, 2014

[12]. S. Kumar, L Budhwar, A. Yadav, M. Yadav and J.P. Yadav, "Phytochemical screening and antibacterial activity of Aloe vera collected from different climatic regions of India", Nat. Prod. J., vol. 6, pp. 73-82, 2016

[13]. F. Nejatzadeh-Barandozi, "Antibacterial activities and antioxidant capacity of Aloe vera" Org. Med. Chem. Lett., vol. 3(5), pp. 2191-2858, 2013

[14]. O.A. Wintola and A.J. Afolayan, "Phytochemical constituents and antioxidant activities of the whole leaf extract of Aloe ferox Mill” Pharm. Mag., vol. 7, pp. 325-333, 2011

[15]. M. M. El-olemy, F. J. Al-muhtadi and A. A. Afifi, "Experimental phytochemistry", A lab. manual, King Fahad Uni. Press; Saudi Arabia, 1994, pp. 3-19,

[16]. J. B. Harbone, "Phytochemical methods", Chapman and Hall, London, 1973, pp. 1-32

[17]. H. O. Edeoga, O. E. Okwu and B. O. M baebie, "Phytochemicals screening of some Nigerian plants", Afr. J. Biotech., vol. 4, pp 585-688, 2005

[18]. H. O. Edeoga, O. E. Okwu and B. O. M baebie, "Phytochemicals screening of some Nigerian plants", Afr. J. Biotech., vol. 4, pp 585-688, 2005

[19]. K.R. Cheruiyot, D. Olila, J. Kateregga, "In Vetro antibacterial activity of selected medicinal plants fronLongisa Region of Bomet District, Kenya”, Afr. Health Sci. vol. 9(1), pp. S42-S46, 2009

[20]. J.M. Andrew, "Determination of MIC", J. of Antimic. Chemotherapy, vol. 48(1), pp. 5-16, 2001

[21]. M.F. Adegboye, D.A. Akinpelu, A.I. Okoh, "The Bioactive and Phytochemical Properties of Garcinia Kola (Heckel) Seed extract on Some Pathogens”, Afr. J. of Biotech., vol. 7(21), pp. 3934-3938, 2008

[22]. E. Raphael, "Phytochemical constituents of some leaves extract of Aloe vera and Azadirachta indica plant species", Glob. Adv. Res. J. Environ. Sci. Toxicol., vol. 1(2), pp. 14-17, 2012

[23]. B. Bouchra, B. Mohammed , H. Hind, B. Nadia, Z. Meryem, E. Hamid, A.D. Naima, B. Narjis and H. Najat, "Chemical composition and antioxidant activity of tannins extract from green rind of Aloe vera (L.) Burm. F.", J. of King S. Uni. - Sci., vol. 31, pp. 11751181, 2019

[24]. F.N Barandozi, "Antibacterial activities and antioxidant capacity of Aloe vera", Org. Med. Chem. Lett., vol. 3, pp. 5, 2003.

[25]. J.H Hamman, "Composition and applications of Aloe vera leaf gel", Molecules, vol. 13, pp. 1599-1616, 2008

[26]. O.P. Vivian, O. Nathan, A. Osano, L. Mesopirr, and W.N. Omwoyo, "Assessmentof the physicochemical properties of selected commercial soaps manufactured and sold inKenya", Open J. App. Sci., vol. 4, pp. 433440, 2014

[27]. O. Atolani, E.T. Olabiyi, A.A. Issa, H. T. Azeez, E.G. Onoja, S.O. Ibrahim, M.F. Zubair, O.S. Oguntoye and G.A. Olatunji “Green synthesis and characterisation of natural antiseptic soaps from the oils of underutilised tropical seed", Sust. Chem. and Pharm., vol. 4, pp. 32 39,2016 